\title{
Description of five new lachryphagous and zoophilous Semiothisa moths from SE Asia, with five new synonymies (Lepid., Geometridae)
}

\author{
Hans BÄNZIGER * and D. S. FLETCHER **
}

With 44 figures

\section{ABSTRACT}

Semiothisa species elephantedestructa n. sp., lannaensis n. sp., suthepensis n. sp. from $\mathrm{N}$ Thailand, hollowayi $\mathrm{n}$. sp. and lacriphaga $\mathrm{n}$. $\mathrm{sp}$. from $\mathrm{N}$ Thailand and also from Sumatra (Indonesia), are described. New synonymies are made with the species eleonora (Stoll, 1780) [= subalbataria (Swinhoe, 1889)], triangulata (Hampson, 1891) [=apatetica Tams, 1924, psammodes (Bastelberger, 1907)], and diplotata Felder \& Rogenhofer, 1874 [=khasiana (Moore, 1888)]. The type series of khasiana sinotibetaria Wehrli, 1932 is mixed, the holotype being identical with diplotata and the paratype belonging to placida (Moore, 1888). All species are illustrated. Male adults suck lachrymal and/or other mammalian body fluids from Ungulata, Proboscidea, and occasionally man.

\section{INTRODUCTION}

In Semiothisa Hübner, 1818, one of the larger genera of geometrid moths, there are several species in which adult males are known to feed on various mammalian body fluids. S. inaequilinea (Warren, 1911) in S Africa, S. eleonora (Stoll, 1780) (previously recorded as $S$. fasciata (Fabricius, 1775)), and possibly $S$. myandaria (Walker, 1863) (needs reidentification as it is most likely S. diplotata Felder \& Rogenhofer, 1874, S. placida (Moore, Thailand.

* Department of Entomology, Faculty of Agriculture, Chiengmai University, Chiengmai,

** Department of Entomology, British Museum (Nat. Hist.), London U.K. 
1888), or S. lacriphaga n. sp.) in Thailand were seen feeding on lachrymation at eyes of ungulates (DU TOIT 1958; BÜTTIKER 1964). More recently S. nora (Walker, 1861), S. placida (recorded as $S$. khasiana sinotibetaria Wehrli, 1932, and as Semiothisa sp. 1), S. elvirata (Guenée, 1857), S. eleonora (as S. fasciata and S. nora), S. triangulata (Hampson, 1891), S. lacriphaga n. sp. and S. hollowayi n. sp. were found to be lachryphagous and/or zoophilous in Thailand, Malaysia, China, and Indonesia (BÄNZIGER 1973, 1983, 1988 , and in prep.).

Some further 20 taxa, presently under systematic analysis, were observed by the senior author during the past decade in SE Asia, especially $\mathrm{N}$ Thailand; they mostly sucked perspiration, wound fluids, mosquito-exuded blood-droplets, but sometimes also lachrymation at eyes of Ungulata, Proboscidea, and occasionally man.

Some species of Semiothisa are very variable in their habitus and may also be exceedingly similar to related taxa, so that often only genitalic analysis can ensure correct identification. Genitalia of nearly all specimens caught were examined, leading to the discovery of several new species and new synonymies, some of which are treated below.

Study of large series collected throughout the year showed that some taxa with identical genitalia have forms with very light coloration and strikingly reduced markings (cf. Figs 1-4, 15-21). Some of these taxa had been given species status in the past but there is convincing evidence that they are only infrasubspecific entities. Namely, (i) the light forms are a seasonal appearance during the dry period of the year (about mid November to about end of April), while the darker ones essentially fly during the rainy season (about May to mid November). (ii) of the more common species, intermediates of all grades between the light and dark forms were found; intermediates tend to fly near the end of the dry hot period. (iii) the fact that light and dark forms recur in several species of Semiothisa.

The presence of light forms during the dry season does not necessarily mean that scarcity of rain is the factor behind the appearance of such forms. In fact the dry period in $\mathrm{N}$ Thailand consists of a cold season, about late November to mid February, and a hot season, about mid February to April. It could well be that temperature, or a combination of temperature and humidity before, at, or after pupation, or some other factor, cause the different colour forms.

Accounts of the Semiothisa fauna of the region (E and SE Asia were given for Borneo and W Malaysia by Holloway $(1976,1982)$, for Taiwan by INOUE (1978), and for Japan by INOUE $(1971,1976,1977)$ and INOUE et al. (1982).

Type material is deposited in the Dept. of Entomology, Fac. of Agriculture, Chiengmai University, Chiengmai, Thailand (DEFACU), the British Museum (Nat. Hist.), London (BMNH), and the Muséum d'histoire naturelle, Geneva, Switzerland (MHNG).

This is the fourth in a series of studies aiming to clarify the taxonomy of zoophilous Lepidoptera, the previous having dealt with some Pyralidae (BÄNZIGER 1987).

\section{DESCRIPTIONS}

Semiothisa lannaensis n. sp.

Figs $5-7,25,26,41$

Holotype ơ, Thailand: Chiengmai Prov., Mae Taeng Distr., Pong Düad, 650 m, 6.X.1982, Bänziger leg., genitalia slide $1472(\mathrm{BMNH})$. 

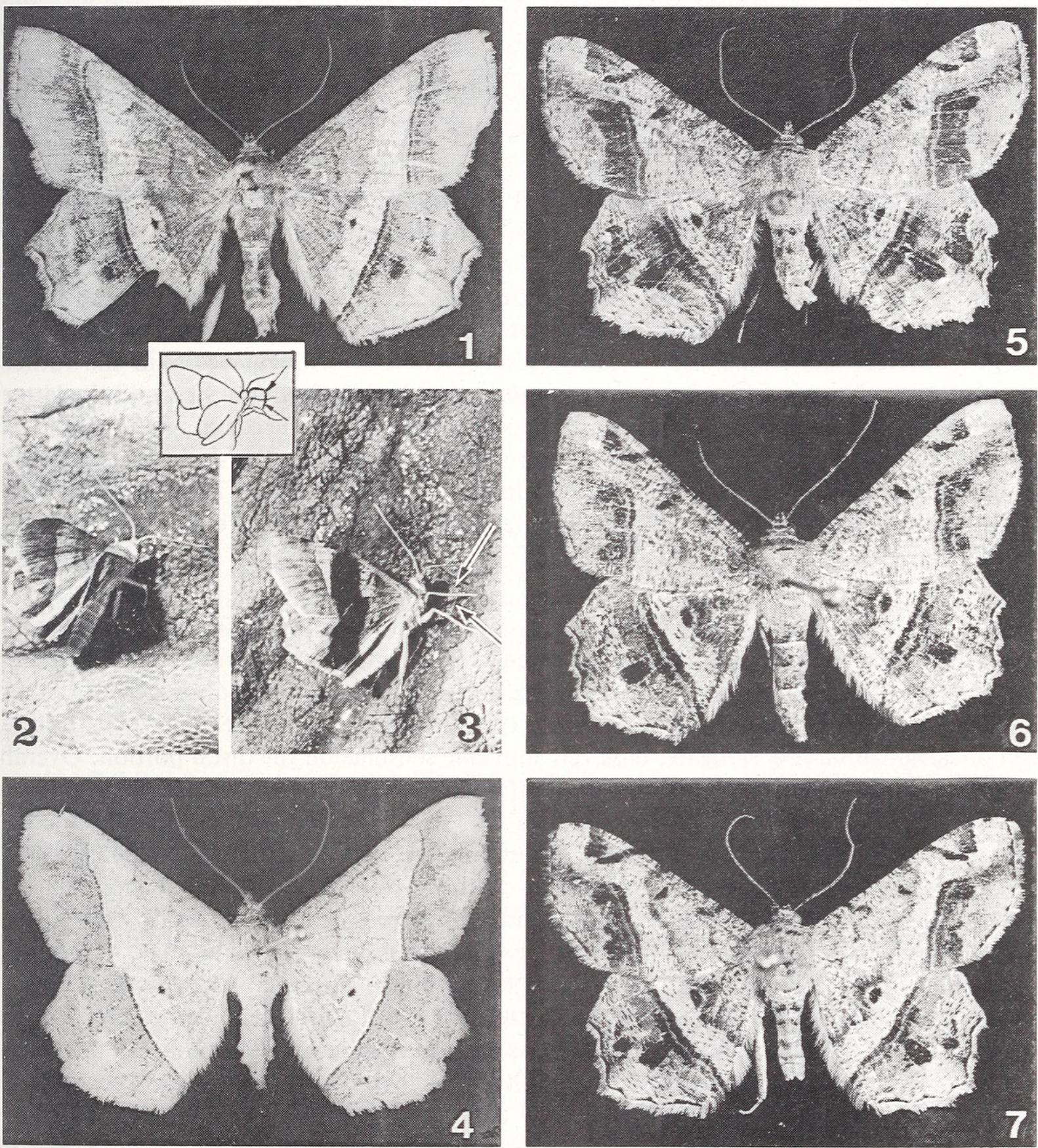

FIGS 1-7.

1-4. Semiothisa elephantedestructa $\mathrm{n}$. sp., holotype (1); paratype (gen. slide 1554) sucking lachrymation below the eye of an elephant shortly before being crushed by the pachiderm's trunk $(2,3)$, insert and arrows showing sucking proboscis; paratype (gen. slide 816) (4). 5-7. Semiothisa lannaensis n. sp., paratype (gen. slide 996) (5); paratype (gen. slide 1438) (6); holotype (gen. slide 1472) (7). 
Paratypes. $50^{*}$, ibid. and 10.IV.1987, genitalia slides 1454 (BMNH), 1435, 1438, 1460, 2415. $30^{\circ}$, ibid. but Huay Nam Dang, 1690 m, 5.VIII., 3.IX.1986, genitalia slides 2235, 2245, 2298. 10 ", Mae Rim Distr., Nong Hoi, 1050 m, 25.X.1981, genitalia slide 996 (DEFACU). 2 o", forest place near Chiengmai-Chiengdao road, km 55, $380 \mathrm{~m}, 23$. X.1980, 8.VIII.1982, genitalia slides 640, 1374 (DEFACU). $1 \mathrm{O}^{\circ}$, NW foot of Doi Chiengdao, $450 \mathrm{~m}$, 5.II.1982, genitalia slide 1493. $5 \mathrm{O}^{\circ}$, Doi Chiengdao, near NW Pass, 1150 m, 9.VI.1984, 28.X.1985, 24.VI., 17.VII., 15.X.1986, genitalia slides 1733, 2004, 2195, 2221 (MHNG), 2339. 6o', Fang Distr., Doi Ang Khang area, 1450 m, 25., 26.IX.1986, 31.X.1987, 27.V.1988, genitalia slides 2313, 2318, 2327, 2338, 2623, 2717. $30^{\circ}$, Mae Nai, Doi Suthep-Pui, 1150 m, 9.VIII.1985, 19.XI.1987, genitalia slide 1954, 2658, 2661. 2 ơ, Mae Ra Aa, Om Koi Distr., 1240 m, 15., 16.III.1985, all Bänziger leg., genitalia slides 1843, 1846 (coll. Bänziger unless otherwise stated).

Derivation of name. The species is named after the region where it has been found, Lan $\mathrm{Na}$, the well-known old Kingdom in $\mathrm{N}$ Thailand.

D i a $\mathrm{g}$ n o s i s. Closest to Semiothisa triangulata, some S. elvirata, and some S. apataria (Swinhoe, 1893), much less to some S. placida, S. diplotata and S. lacriphaga sp. nov. Differs from all these - but especially from $S$. triangulata - in the rather rounded inner fore wing margin and tornus. It is also distinct from the first and the latter two in having the inner corner of the triangle-shaped blotch on the costal margin near the apex of the fore wing truncate, thus forming a trapezoid (more or less acutely triangular in the other species). The underside of the wings of $S$. elvirata and S. apataria have wide areas of deep yellow which are greyish in S. lannaensis. Genitalic differences are clear as shown below.

D e s c r i p tio $n$. Male (Figs 5-7). Wingspan 25-30 mm, $\varnothing=28 \mathrm{~mm}, \mathrm{n}=16$. Head, antenna, palpus, thorax and abdomen greyish brown above; underside of these, and the legs, somewhat lighter, often irrorate with tiny dark dots. Proboscis, as in other zoophilous Geometridae, of the generalized type though comparatively short, with little sclerotization and a few elongate, passively movable sensillae on the distal portion. Overall colour of wings upperside greyish brown, patterned as on Figs 5-7. Fore wing: This is narrow because the inner margin and the tornus are rather rounded. Antemedial and medial fasciae as in $S$. elvirata and $S$. apataria but less well defined than in $S$. placida and $S$. lacriphaga; unlike these the area basad of the medial fascia is much more darkly irrorate than the band between the medial and the postmedial fasciae; inner corner of the costal triangle-shaped blotch near the apex is truncate, giving rise to a trapezoid, somewhat like that present in S. apataria and S. elvirata, while in the other 3 species it is more or less triangular; discal dots more conspicuous than in the 5 species mentioned.

Hind wing: The dark blotch just distal to the postmedial between veins M3 and Cula is quite conspicuous (much more so than in the latter two, comparable to the former two, but less so - and also less well defined - than in S. triangulata); an additional dark blotch is often present distally to this, but again less well developed and defined than in $S$. triangulata, comparable to that sometimes present in S. elvirata, and missing in the other 3 species; cilia similar to those in S. lacriphaga. Underside of wings much darker than upperside, especially the area distal to the postmedial which is dark brownish grey to nearly black; medial quite broad. The underside is quite similar to that of S. triangulata, quite darker than the more brownish one of S. lacriphaga, S. diplotata, and $S$. placida, and very different from that of $S$. elvirata and $S$. apataria which have extensive yellow areas.

Female. Unknown. 
Male genitalia (Figs 25, 26, 41). Dorsal lobe of valve narrow, straight and with roughly parallel margins; ventral lobe recurved and tapering except near the tip where it widens again slightly without any processes. Aedeagus with a patch of denticle-like cornuti. 8th sternite with a pair of short, sclerotized extensions each with (Fig. 41) or without a small flat lobe. Close to $S$. triangulata but in this the ventral lobe of the valve is narrow and elongate; the 8th sternite is more concave between the two sclerotized extensions which are also narrower; the aedeagus is of different shape, shorter and without the finger-like body. The genitalia of $S$. apataria and $S$. elvirata are closely related but quite distinct in having more or less conspicuous processes on the ventral lobe of the valve. Holotypes/lectotypes of all the above species were examined.

B i o 1 o g y . Immature stages unknown. A male was found sucking lachrymation from the eye of a zebu (Bos taurus indicus (L.)), one sucked perspiration from the author's trousers, four imbibed a sodden mixture of earth, rainwater, urine and dung, one settled on fresh dung of elephant (Elephas maximus L.) and another flew near this (Bänziger, in prep.).

Distribution. N Thailand, at altitudes from 380 to $1700 \mathrm{~m}$.

\section{Semiothisa elephantedestructa $\mathrm{n}$. $\mathrm{sp}$.}

Figs 1-4, 22-24, 44

Holotype o , Thailand: Chiengmai Prov., forest place off road Chiengmai-Chiengdao, approx. km 55, 450 m, 6.III.1984, Bänziger leg., genitalia slide 1675 (BMNH).

Paratypes. 3 o $^{*}$ ibid., 370, 420 and 500 m, 8.VIII.1981, 23.IV.1983 and 1.III.1988, Bänziger leg., genitalia slides 816,1554 and 2678 (coll. Bänziger). (Of the second only the genitalia are extant, besides 2 colour photographs (Figs 2, 3, in black and white) of the moth while sucking lachrymal fluid below the eye of an elephant, taken before it was crushed and damaged by the pachiderm's trunk.)

Derivation of name. The species is so named to commemorate the unfortunat incident mentioned above.

D i a $\mathrm{g}$ n o s i s. Close to S. epicharis Wehrli, 1932, S. inchoata (Walker, 1861) and some dry season forms of S. eleonora. However, the triangle on costal margin near the apex of the fore wing is missing in S. elephantedestructa and the postmedial fascia is less acutely angled near the costa. Genitalic differences are clear as noted below.

D e s c r i p t i o n. Male (Figs 1-4). Wingspan 31-37 mm. Head, antenna, palpus, proboscis, thorax and abdomen above as in S. lannaensis but somewhat darker and more brownish; underside of these, and the legs, dark yellow to brownish yellow. Overall colour of wings upperside light to dark greyish with whitish, yellowish and brownish markings, patterned as on Figs 1-4. Fore wing: Costal triangular blotch near apex is missing (conspicuous in related species, faint only in some light forms of S. epicharis and S. eleonora); antemedial and medial fasciae indistinct in the light, dry season form (cf. introduction), overshadowed in the dark one; postmedial well defined and, except the very tip near the fore wing margin, more or less straight instead of angled round the proximal side of the triangular blotch as in the related species. In the dark form both wings are grey except for a band between the medial and postmedial, which is whitish grey suffused with darkish spots; in the light form the band extends from base to postmedial; discal spots clear; a dark blotch (and a much less distinct one on vein M2) may or may not be present just distally to the centre of the wing between veins M3 and Cula. Wings underside with yellow base, white fascia between medial and postmedial - both dusted with black - and area distally of postmedial greyish with some white flecks. 
Female. Unknown.

Male genitalia (Figs 22-24, 44). Not closely related to any of the over twenty SE Asian species known to the senior author. Dorsal lobe of the valve broadened proximally at the middle; ventral lobe of quite unusual shape, short, with the distal portion sclerotized and recurved inwardly. Aedeagus with some tooth-like, sclerotized cornuti and many tiny denticles on vescica. 8th sternite widely and deeply excised distally, the extensions being broad and widened laterally. The genitalia are thus strikingly different from those of the externally similarly looking $S$. epicharis, in which the ventral lobe of the valve is narrow and long, besides other differences. Also very different from $S$. eleonora in which the ventral lobe is first broad but then abruptly narrowed into a point, among other differences. The holotype of S. inchoata is a female; since the habitus is strikingly close to some S. subalbataria (Swinhoe, 1889), S. inchoata may be yet another synonym of S. eleonora (cf. p. 950), or S. nora.

The holotypes of all the above mentioned species were examined, though for $S$. inchoata only the facies were studied, not the genitalia.

B i o 1 o g y. Immature stages unknown. Male adults are oligolachryphagous, one specimen was seen sucking lachrymal secretion on an elephant (Figs 2, 3), one took wound exudates from a sore of an elephant and another imbibed perspiration from the senior author's skin (Bänziger, in prep.).

Distribution. N Thailand.

Comment. The appearance of light and dark forms in several Semiothisa has been mentioned in the introduction.

Semiothisa suthepensis $\mathrm{n}$. $\mathrm{sp}$.

Figs $10,11,27,28,40$

Holotype ơ, Thailand: Chiengmai Prov., Mae Nai, Doi Suthep-Pui, 1150 m, 9.VIII.1985, Bänziger leg., genitalia slide 1953 (BMNH).

Paratypes. $10^{*}$, ibid. but 6.XI.1987, genitalia slide 2642. $20^{\circ}$, forest place off road ChiengmaiChiengdao, approx. km 55, 380 and 420 m, 2.I.1982 and 29.X.1983, all Bänziger leg., genitalia slides 1633 (DEFACU), 1063 and 2642 (coll. Bänziger).

Derivation of name. The species is named after one of the places where it has been found, the famous Mount Suthep.

D i a $\mathrm{g} n$ o s is. Similar to no other Semiothisa except the palaearctic defixaria (Walker, 1861). But in S. suthepensis the costal triangle-shaped blotch near the fore wing apex is not evident and there is no whitish area there. The genitalia are very different as shown below.

D e s c r i p t i o n. Male (Figs 10, 11). Wingspan 24-29 mm. Head, antenna, palpus, proboscis, thorax, legs, abdomen as in S. lannaensis though somewhat lighter coloured. Overall colour of fore wings upperside very light to medium greyish dusted with minute dark speckles, patterned as in Figs 10, 11. Fore wing: Antemedial strongly undulated, diffuse to well-defined; medial straight, and rather more evident; postmedial diverging at the inner margin near the tornus into a somewhat faint line (barely visible, if at all, in S. defixaria) quite parallel to the medial, and a more obvious, initially double line running towards the anterior margin near the apex; just before reaching this the line turns off in a more or less acute angle (rather rounded in S. defixaria) to rejoin the fainter branch near the fore margin. The costal triangle-shaped blotch near the apex is not evident 

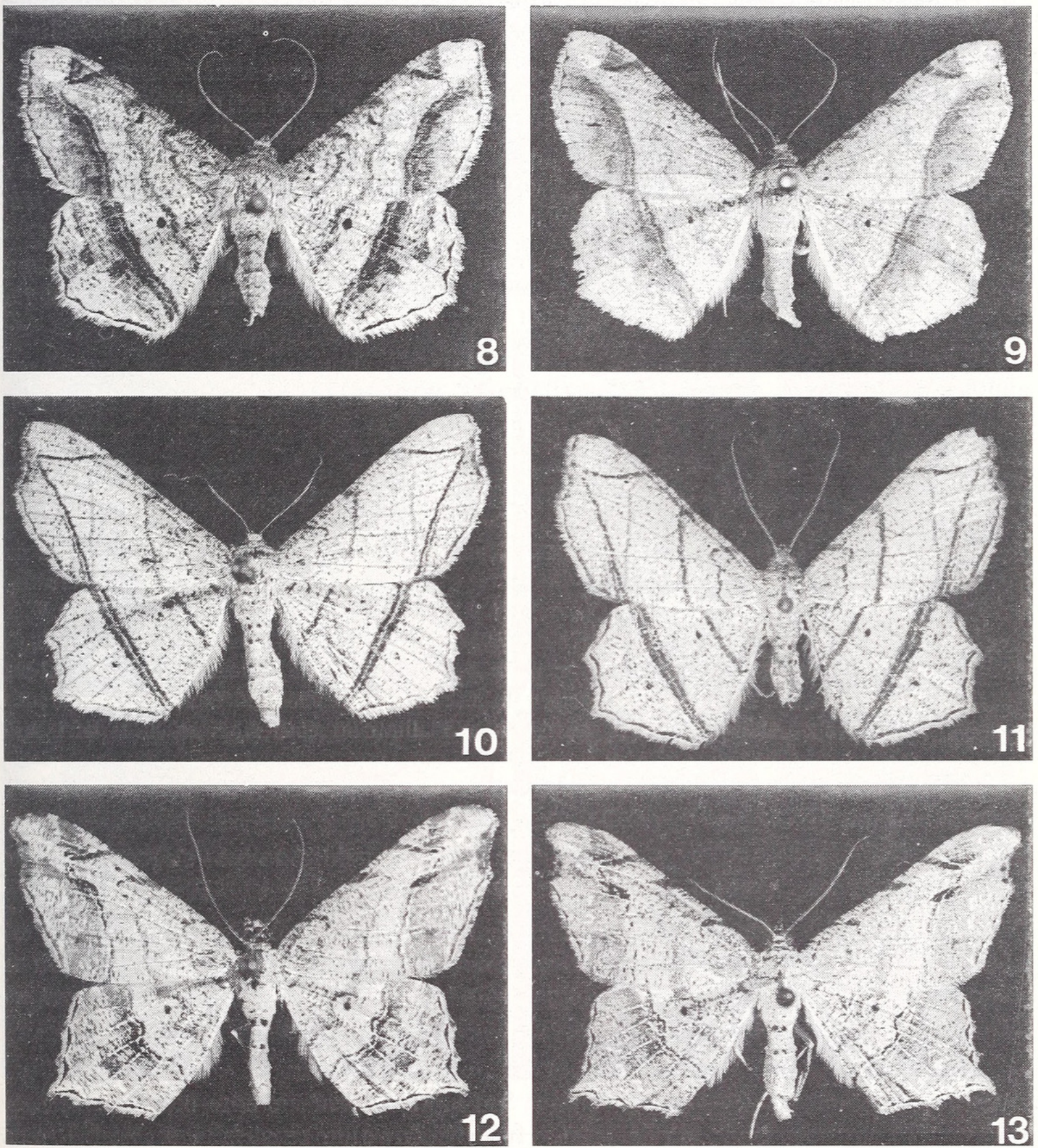

FIGS 8-13

8-9. Semiothisa lacriphaga n. sp., paratypes (gen. slides 1316, 1190) (8, 9). 10, 11. Semiothisa suthepensis n. sp., paratype and holotype (gen. slides 1063, 1953) (10, 11). 12-13. Semiothisa hollowayi n. sp., paratype and holotype (gen. slides 783, 661) $(12,13)$. 
(present in S. defixaria) and the area near the apex is coloured as the rest of the wing (whitish in $S$. defixaria). Discal spot not evident.

Hind wing: Antemedial ve short, medial and postmedial alsc straight, the latter very evident, consisting of two parallel lines. Discal spots and blotch distal to the postmedial between veins M3 and Cula faint to very small.

Wings underside much lighter; fore wing area between the two divergent pos tial branches yellow, dark near the inner margin; hind wing area distal to th po yellowish dusted with dark spots; otherwise similar to the upperside.

Female. Unknown.

Male genitalia (Figs 27, 28, 40). Very different from S. defixaria. Dorsal lobe without the conspicuous finger-like extension of $S$. defixaria, ventral lobe of valve long, slender, ventrally recurved (short, obtuse in $S$. defixaria), aedeagus similar as in $S$. lannaensis (patch of denticles and shape different in S. defixaria), 8th sternite shallowly excised distally and little sclerotized (deeper excised and more sclerotized in $S$. defixaria).

The holotype of $S$. defixaria is without abdomen; the genitalia BM 11977 of a specimen from Shantung, N China, nearest to the type locality, were examined.

B i o 1 o g y. Immature stages unknown. One male adult sucked skin secretions, another tried to settle, on an elephant (Bänziger, in prep.).

Distribution. N Thailand.

\section{Semiothisa hollowayi sp. nov.}

Figs $12,13,29,30,43$

Holotype ơ, Thailand: Chiengmai Prov., forest place near road Chiengmai-Chiengdao, km 55, 380 m, 14.XI.1980. Bänziger leg., genitalia slide 661 (DEFACU).

Paratypes. $1 \sigma^{\circ}$, ibid., 4.VII.1981, genitalia slide 783 (BMNH). $1 \sigma^{\circ}$, Doi Saket, 28.VIII.1966, genitalia slide 2032. IndONESIA: $1 \sigma^{\circ}$, N Sumatra, Aek Nauli, $1150 \mathrm{~m}$, all Bänziger leg., 12.IV.1983, genitalia slide 1510 (coll. Bänziger).

Derivation of name. The species is named in honour of Dr. J. D. Holloway in acknowledgement of his extensive knowledge about SE Asian Macrolepidoptera and for his help to the authors.

$\mathrm{D}$ i a $\mathrm{g}$ n o s is. The new species cannot be distinguished from $S$. emersaria (Walker, 1861) on external characters but the genitalic structures are clearly distinct as described below.

D e s c r i p t i o $n$. Male (Figs 12-13). Wingspan 28-30 mm, $\varnothing=29, \mathrm{n}=3$. Head, palpus, thorax, abdomen above greyish white, below lighter; antenna brown, legs greyish irrorate with dark? Proboscis structure as in S. lannaensis. Overall colour of wings upperside light greyish with brownish areas and few dark markings, patterned as on Figs 12, 13. Fore wing: Antemedial fascia incomplete, medial variably marked, distinct to thoroughly diffuse or absent; postmedial clear to incomplete; discal spot very faint or absent; a small black rhomboidal streak is below the costal triangular to trapezoidal blotch near the apex. Hind wing: Medial fascia well to ill defined; postmedial quite clear, sometimes double; discal spot small but apparent. Underside of wings whitish irrorate with brownish, with an irregular dark medial and the area distal to the postmedial brown except for a whitish area near the apex.

Female. Unknown. 

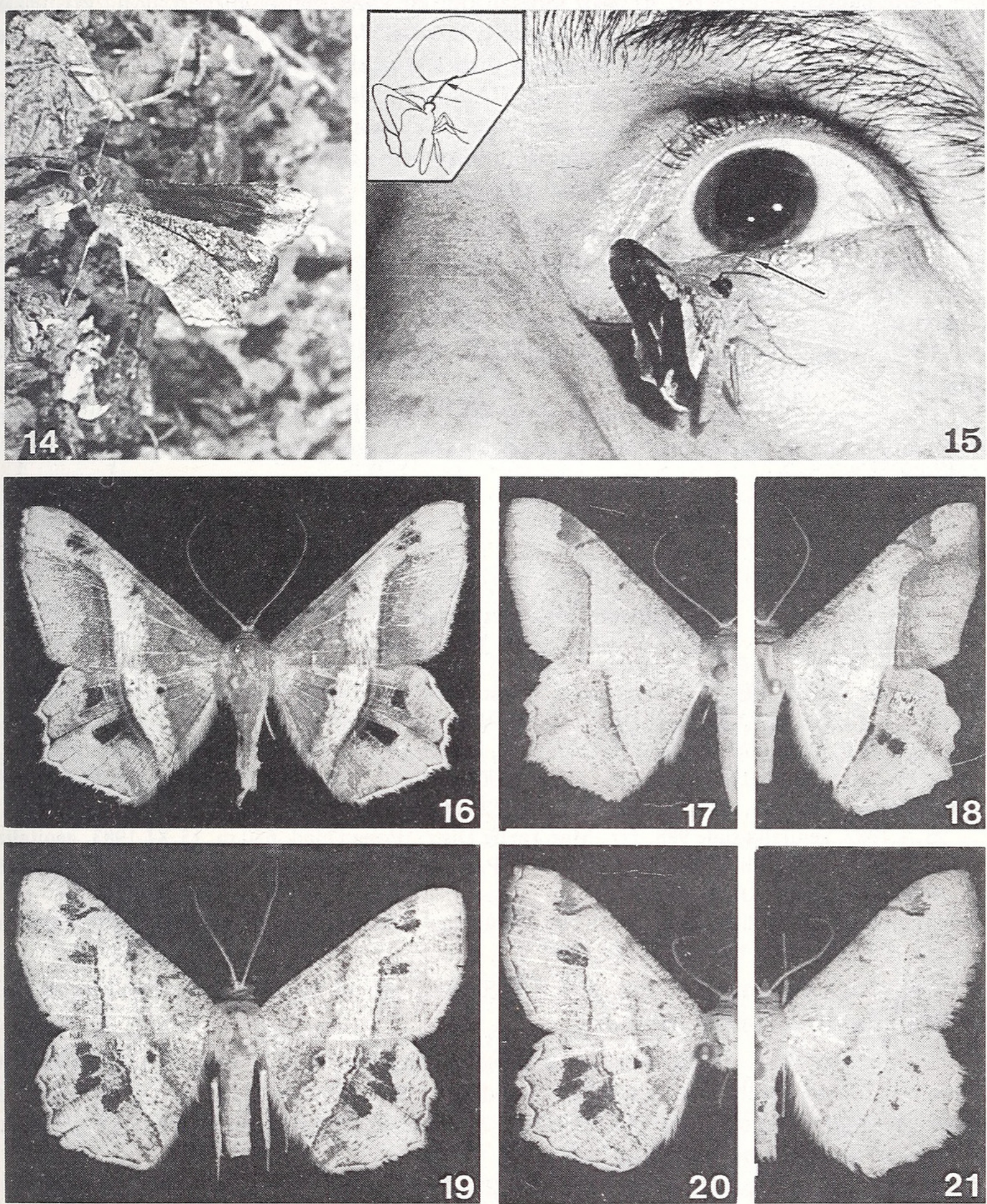

Figs 14-21.

14. Semiothisa diplotata F. \& R. feeding on a sodden mixture of earth, rainwater, urine and dung of pig (gen. slide 2295). 15-18. Semiothisa eleonora (Stoll). Specimen (gen. slide 1549) sucking lachrymal fluid from the eye of the senior author who photographed himself. The attack occurred while he was studying elephants in a jungle in N Thailand on the moon-lit night of 23.IV.1983 (insert and arrows showing position of sucking proboscis) (15). Rainy season, dark form (gen. slide 1933) (16); dry season, light form (gen. slide 1142) (17); intermediate form (gen. slide 1842) (18). 19-21. Semiothisa triangulata (Hampson). Rainy season, dark forms (gen. slides 1571, 1139) (19, 20), dry season, light form (gen. slide 1316) (21). 
Male genitalia (Figs 29, 30, 43). Dorsal lobe of valve gently curved along posterior margin, ventral lobe tapering quite rapidly into a blunt tip. Aedeagus with minute denticles on vescica and a large cornutus with the apex and parts of the wall serrate. Related to $S$. emersaria but quite distinct. The ventral lobe of the valve of $S$. emersaria does not taper towards the tip but remains wide, with more or less parallel margins, except near the tip where it widens again slightly before being abruptly truncate. The holotype BMNH geometrid genitalia slide 11741 was studied.

B i o l o g y. Immatures unknown, but on two occasions a last instar larva of S. emersaria was found suspended from a Delonix regia (Boj.) Rafin. tree. Adult males of S. hollowayi were observed flying around water buffalo (Bubalus bubalis (L.)) and sucked elephant's secretions and excretions (BÄNZIGER 1988 and in prep.).

Distribution. N Thailand, and Sumatra in Indonesia, at altitudes of up to at least $1100 \mathrm{~m}$.

Comments. The species is sympatric with $S$. emersaria in N Thailand. They have been found at the same place, near the same host but at slightly different times.

\section{Semiothisa lacriphaga $\mathrm{n}$. $\mathrm{sp}$.}

Figs $8,9,31,32,42$

Holotype ơ, ThaILAnd: Chiengmai Prov., forest place near road Chiengmai-Chiengdao, km 55, $680 \mathrm{~m}, 10$. VII.1982, Bänziger leg., genitalia slide 1310 (BMNH).

Paratypes. 110 , ibid. and 380, 400, $500 \mathrm{~m}$, 13.V., 8.VIII, 28.XI.1981, 2.I., 20.III., 10.VII.1982, 6., 20.IV.1984, 16.III.1988, genitalia slides 1200 (BMNH), 1316, 1687 (both DEFACU), 1065 (MHNG), 770, 823, 824, 1012, 1190, 1696, 2688. 1 o , Mae Rim Distr., Nong Hoi, 1000 m, 25.X.1982, genitalia slide 988. 1 ơ, Mae Taeng Distr., Pong Düad, 650 m, 15.XI.1983, genitalia slide 1471. $1 \mathrm{O}^{\prime}$, Doi Chiengdao, near NW Pass, $1100 \mathrm{~m}$, 3.III.1983, genitalia slide 1496, all Bänziger leg. (coll. Bänziger).

Additional material studied. IndonesiA: $10^{*}$, N Sumatra, Aek Nauli, 1150 m, 12.IV.1983, Bänziger leg., genitalia slide 1519 (coll. Bänziger).

Derivation of name. The species is named after one of the moth's feeding habits, i.e. the imbibing of lachrymal secretion.

D i a $\mathrm{g} n$ o s i s. Very close to Semiothisa diplotata and S. placida from which it is not possible to safely distinguish on the basis of the facies only though $S$. diplotata is generally slightly larger. Also near to the $S$. myandaria complex. However, the genitalic differences are clear as shown below.

D e s c r i pti o n . Male (Figs 8, 9). Wingspan 25-30 mm, $\varnothing=27 \mathrm{~mm}, \mathrm{n}=13$. Head, antenna, palpus, proboscis, thorax and abdomen as in $S$. lannaensis but head and patagia often somewhat darker. Underside of these, and the legs, more yellowish brown, often irrorate with tiny dark dots. Overall colour of wings upperside greyish brown, patterned as on Figs 8, 9. Fore wing antemedial and medial fasciae usually present as narrow but not too conspicuous lines; postmedial generally dark, often quite well-defined and consisting of two parallel lines, the outer line fading at apex; distally to the postmedial the wing is darker; inner corner of the costal triangle-shaped blotch near the apex usually acute, sometimes blunt but always conspicuous; discal spot inconspicuous; terminal dots very small but sharply defined, lined distally by a yellowish white line; cilia greyish brown. Hind wing: similar to fore wing but antemedial fascia missing; medial, postmedial and 
discal spot are often more evident than in the fore wing; a dark, often conspicuous but sometimes nearly imperceptible or ill-defined spot is present just distally to the postmedial between veins M3 and Cula. Rest as in fore wing.
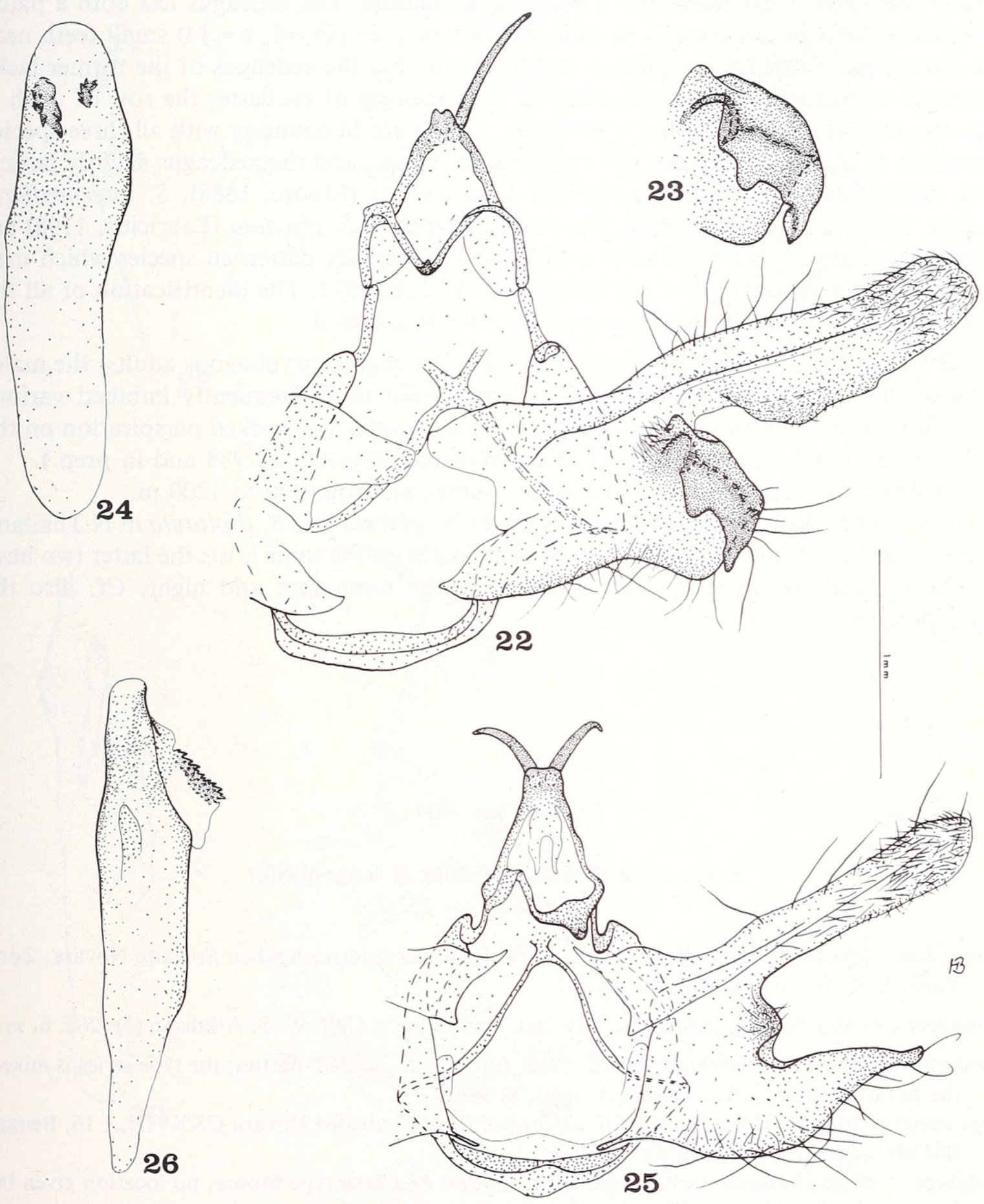

Figs 22-26.

22-24. Male genitalia of Semiothisa elephantedestructa $\mathrm{n}$. sp., variations of the ventral lobe of the valve (23), aedeagus (24). 25-26. Male genitalia of Semiothisa lannaensis n. sp., aedeagus (26). 
Wings underside with stronger contrasts, otherwise corresponding to the upperside though the postmedial lines become more of a wide, dark band. A white fleck near the apex and a larger one about in the middle of the fore wing are often well defined and conspicuous, while there is often only a hint of them on the upperside.

Female. Unknown.

Male genitalia (Figs 31, 32, 42). Characteristically the ventral margin of the dorsal lobe of the valve is extended into a point in the middle. The aedeagus has both a patch with many denticle-like cornuti as well as a row of 2-15 $(\varnothing=8, n=14)$ small teeth near the distal edge. Close to $S$. diplotata and $S$. placida but the aedeagus of the former lacks the patch of denticle-like cornuti while on the aedeagus of the latter the row of teeth is missing; one large cornutus and a spinulose vescica are in common with all three species though in $S$. diplotata they are somewhat more robust, and the aedeagus slightly larger. Also quite distinct from the genitalia of $S$. horridaria (Moore, 1888), S. intermediaria (Leech, 1897), and S. myandaria. The male syntypes of $S$. pluviata (Fabricius, 1798) are without genitalia; it is a somewhat smaller and differently patterned species which may well be a senior synonym of $S$. stenotrigonum Wehrli, 1932. The identification of all the above species is based on holotypes unless otherwise stated.

B i o l o g y. Immature stages unknown. As oligolachryphagous adults, the males occasionally sucked lachrymation from elephant but more frequently imbibed various body fluids from this and from water buffalo; the moths also sucked perspiration on the author's hand and from the clothes of his assistant (BÄNZIGER 1988 and in prep.).

Distribution. Thailand and Indonesia (Sumatra), from 300 to $1200 \mathrm{~m}$.

Comments. S. lacriphaga is sympatric with S. placida and S. diplotata in N Thailand where it has been found with either in the same night on the same host; the latter two have also been caught at mercury vapour lamps at the same spot and night. Cf. also the synonymic notes on the latter two.

\section{SYNONYMIC NOTES}

\section{Semiothisa diplotata Felder \& Rogenhofer}

Figs 14, 34, 35

Semiothisa diplotata Felder \& Rogenhofer, 1874, Reise der österreichischen Fregatte Novara. Zool. Theil, Bnd. II, Abt. 2, Tb. 78, Fig. 16.

Gonodela khasiana Moore, 1888, Desc. new Ind. lepid. Insects Coll. W. S. Atkinson (3): 262, n. syn.

Semiothisa khasiana sinotibetaria Wehrli, 1932, Int. ent. Z. 26: 340, partim; the type series is mixed, the paratype being a $S$. placida (cf. this), n. syn.

Type material studied. Holotype o of $S$. diplotata: InDIA. Labelled Novara CXXVIII, f 16, Bengal, BMNH geometrid genitalia slide 11350 .

Holotype or of S. khasiana: INDIA. Labelled Gonodela khasiana type Moore, no location given but seems to be Assam, BMNH geometrid genitalia slide 11303.

Holotype $\sigma^{\prime}$ of S. khasiana sinotibetaria: CHINA. Labelled Ta-tsien-Lou, Chasseurs Indigènes du Père Déjean, 1903. There are three lables seemingly handwritten by Wehrli: "S. sinotibetaria Wehrli Typ"; "S. khasiana Moore sinotibetaria Wehrli Typ"; and (translated from German by the senior author) "after Prout ?form of khasiana Moore though underside different". Genitalia slide ZMFK-Nr. 895 in Museum Alexander Koenig, Bonn. 

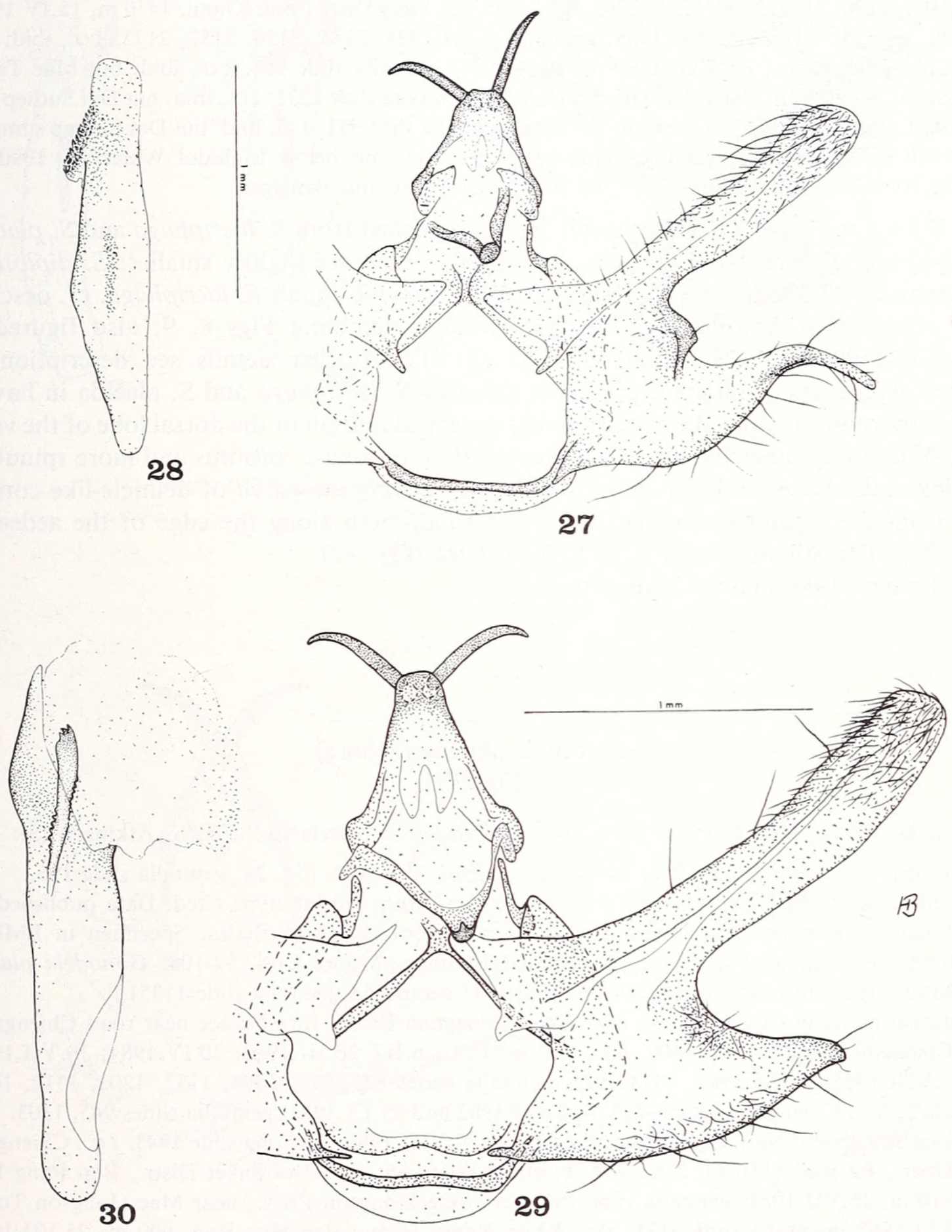

FIGS 27-30.

27-28. Male genitalia of Semiothisa suthepensis n. sp., aedeagus (28). 29-30. Male genitalia of Semiothisa hollowayi n. sp., aedeagus (30). 
Additional material studied. 21 o , ThaIland: Chiengmai Prov., Doi Chiengdao, NW Pass, 1100 m, 30.I.1985; 20.II.1986; 3.III.1983；4.III.1985； 7.III.1984；2.IV.1986；21.IV.1984；14.V.1984; 9.VI.1984; 24. and 25.VI.1986; 17.VII.1986; 31.VII.1985; 21.VIII.1986; 28.X.1985, genitalia slides 1497, 1676, 1700, 1722, 1732, 1821, 1841, 2010, 2057, 2058, 2059, 2060, 2116, 2121, 2123, 2194, 2196, 2199, 2200, 2225, 2295. 5 o", ibid. but Fang Distr., Ban Khom, 1450 m, 15.IV.1986; 20. and 21.V.1986; 31.VII.1985, genitalia slides 1934, 2134, 2136, 2152, 2172. $1 \mathrm{O}^{\circ}$, ibid. but Chiengdao Distr., Pa Kia, 1550 m, 20.X.1981, genitalia slide 964. 1 ơ, ibid. but Mae Taeng Distr., Huay Nam Dang, 1690 m, 5.VIII.1986, genitalia slide 2232. 1 ơ, ibid. but Doi Suthep-Pui Natl. Park, Mae Nai, 1150 m, 30.IX.1981, genitalia slide 951. 1 o $^{*}$, ibid. but Doi Suthep summit, 1610 m, 16.IX.1981, genitalia slide 924. 1 o , ibid. but below Mahidol Waterfall, 1090 m, 15.III.1986, genitalia slide 2107; all Bänziger leg., in coll. Bänziger.

$\mathrm{D}$ i a $\mathrm{g} \mathrm{n}$ o s i s. Cannot safely be distinguished from S. lacriphaga and S. placida on the basis of external characters alone though they are slightly smaller: S. diplotata, wingspan 27-32.5 mm, $\varnothing=30.3 \mathrm{~mm}, \mathrm{n}=32$; S. placida equals $S$. lacriphaga, cf. description. Habitus of $S$. diplotata (Fig. 14) closely resembling Figs 8, 9; also figured in BARLOW (1982, p. 128, plate 43, Fig. 12). For further details see description of $S$. lacriphaga. The genitalia differ from those of $S$. lacriphaga and S. placida in having a less pronounced point-like extension on the ventral margin of the dorsal lobe of the valve (Fig. 35), in the somewhat larger aedeagus and more robust cornutus and more spinulous vescica, and above all differs from the first in lacking the patch of denticle-like cornuti and from the second in having the row of small teeth along the edge of the aedeagus (Fig. 34). The 8th sternite is as in S. lacriphaga (Fig. 42).

Biology. Like that of $S$. lacriphaga.

\section{Semiothisa placida (Moore)}

Fig. 33

Gonodela placida Moore, 1888, Descr. new Indian lepid. Insects Coll. W. S. Atkinson (3): 262.

Semiothisa sp. 1, BÄNZIGER 1973, Revue suisse Zool. 79: 1400, Fig. 24, genitalia slide 196.

Type material studied. Syntype on on of S. placida: INDIA. No holotype cited. Data published as: Calcutta, Bombay. Specimens in BMNH and Zool. Museum Berlin. Specimen in BMNH, herewith designated as lectotype, labelled Bombay: Moore Coll. 94-106: Gonodela placida Moore type (in Moore's handwriting), BMNH geometrid genitalia slide 11351.

Additional material studied. THAILAND: $80^{\circ}$, Chiengmai Prov., forest place near road ChiengmaiChiengdao, km 55, 380, 400, 500, 680 m, 16.I., 6.II., 20.III.1982; 20.IV.1984; 10.VII.1982; 8.VIII.1981; 24.IX.1983; 14.X.1981, genitalia slides 825, 977, 1094, 1152, 1203, 1312, 1606, 1695. $2 \sigma^{\prime}$, Chiengmai Town, 315 m, 7.VII.1982 and 23.IX.1981, genitalia slides 945, 1303. $1 \sigma^{\circ}$, Doi Suthep-Pui Natl. Park, Mae Nai, 1150 m, 9.VIII.1985, genitalia slide 1943. 1 ơ, Chiengdao Distr., Pa Kia, 1550 m, 2.X.1981, genitalia slide 965. 1 o , Doi Saket Distr., Ban Pang Hai, 910 m, 16.VII.1981, genitalia slide 798. 1 \% , Mae Hongson Prov., near Mae Hongson Town, 12.I.1967, genitalia slide 1131. 1 ơ, Khun Yuom Distr., Ban Hua Pon, 900 m, 25.VII.1983, genitalia slide 1574. 1 o $^{\prime}$, Saraburi Prov., Muag Lek, II.1966, genitalia slide 196. ChINA: $10^{\prime}$, Yünnan Prov., Hsi Shuang Banna Auton. Distr., Hsiao Meng Lun, 560 m, 16.VI.1981, genitalia slide 850, all Bänziger leg., in coll. Bänziger.

The paratype of $S$. khasiana sinotibetaria Wehrli also belongs to S. placida while the holotype of this mixed series sinks to $S$. diplotata (cf. there). Paratype on of $S$. khasiana sinotibetaria labelled: CHINA, Chasseurs indigènes des Missionnaires de Ta-tsien-Lou, 1906: Brit. Mus. 1962-360 (ex Wehrli coll.), genitalia slide 11664, in BMNH. The species 

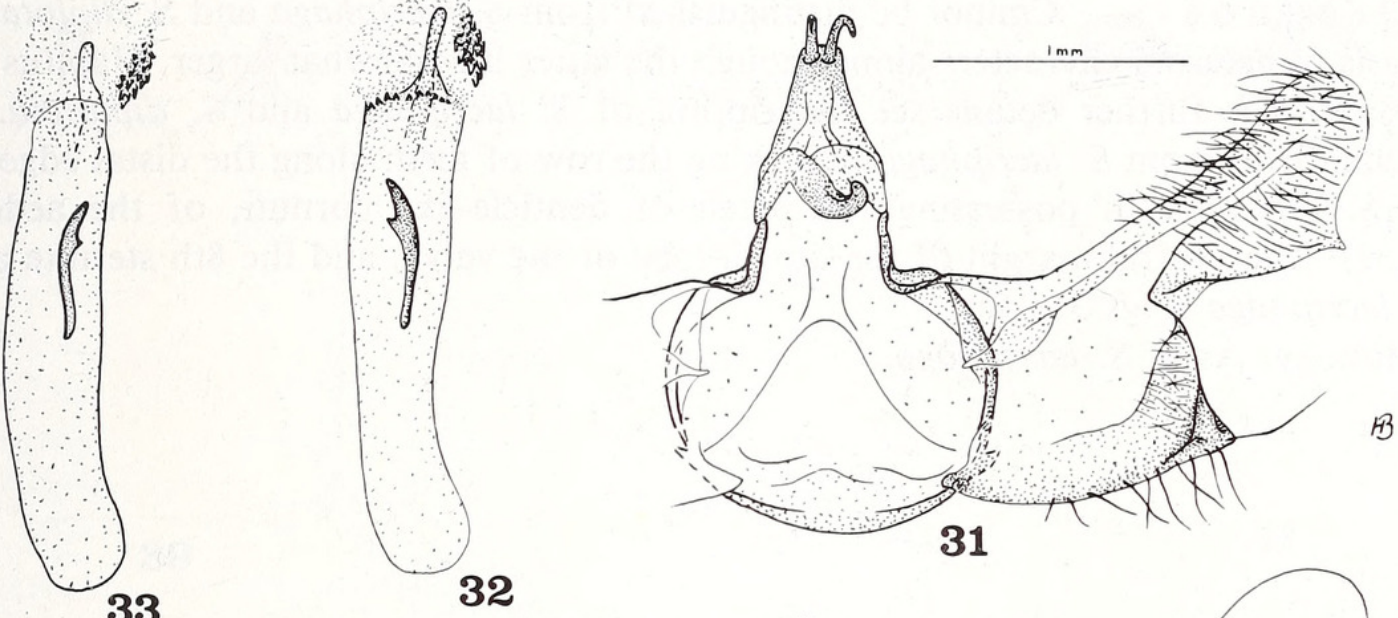

33

32

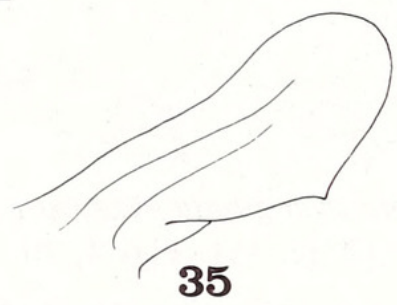

34
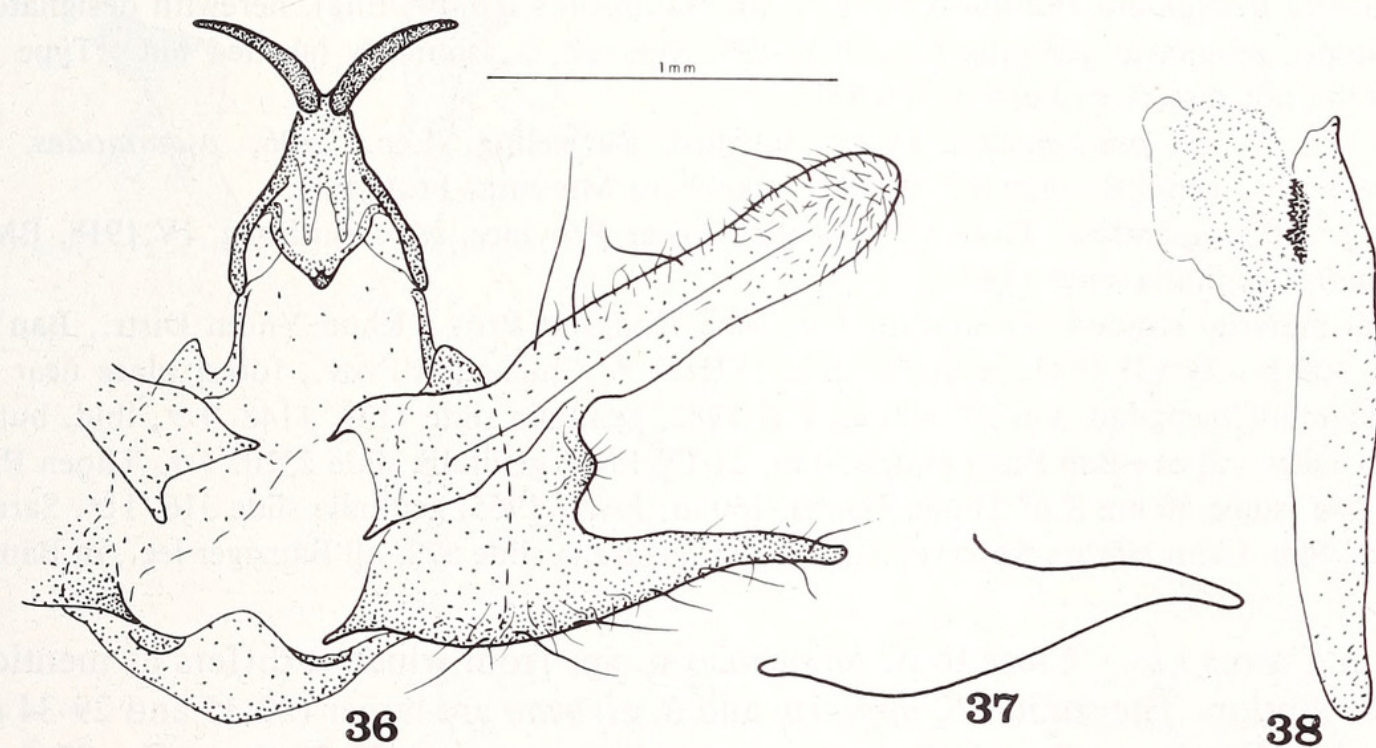

FIGS 31-38.

31-32. Male genitalia of Semiothisa lacriphaga n. sp., aedeagus (32). 33. Aedeagus of Semiothisa placida (Moore). 34-35. Aedeagus (34) and dorsal lobe of valve (35) of Semiothisa diplotata F. \& R. 36-38. Male genitalia of Semiothisa triangulata (Hampson), variation of the ventral lobe of valve (37) and aedeagus (38). 
mentioned as S. khasiana sinotibetaria in BÄNZIGER 1983, Mitt. schweiz. ent. Ges. 56: 79, was identified on the basis of the BMNH paratype and therefore also represents S. placida.

D i a g n o s i s. Cannot be distinguished from S. lacriphaga and S. diplotata on the basis of external characters alone though the latter is somewhat larger. Habitus as in Figs 8, 9. For further details see description of $S$. lacriphaga and S. diplotata. The genitalia differ from $S$. lacriphaga in lacking the row of teeth along the distal edge, and from $S$. diplotata in possessing the patch of denticle-like cornuti, of the aedeagus (Fig. 33). The ventral margin of the dorsal lobe of the valve, and the 8th sternite are as in S. lacriphaga (Figs 31, 42).

Biology. As in S. lacriphaga.

\section{Semiothisa triangulata (Hampson)}

Figs 19-21, 36-39

Gonodela triangulata Hampson, 1891, Illustr. typical specimens Lepid. Heterocera Coll. Br. Mus. 8: 112, pl. 151, Figs 4, 10.

Gonodela psammodes Bastelberger, 1907, Jb. nassau. Ver. Naturk. 60: 88, n. syn.

Semiothisa apatetica Tams, 1924, J. Nat. Hist. Siam Soc. 6: 271, pl. 17, Fig. 6, n. syn.

Type material studied. Syntype or of $S$. triangulata: InDIA, labelled Nilgiris, Hampson Coll. 89-129, Gonodela triangulata Hampson Type o (in Hampson's handwriting), herewith designated as lectotype, geometrid genitalia slide 1950-197. Syntype $\subsetneq$, similarly labelled but "Type $९$ "; genitalia not dissected; both in BMNH.

Holotype $O^{\prime}$ of $S$. psammodes: InDIA, labelled Darjeeling, Lep. 2706, psammodes, coll. Bastelberger, genitalia slide 4.2706 in Senckenberg Museum, Frankfurt.

Holotype o of $S$. apatetica: ThaILAND, labelled Phrae Province, Mae Sai Song, IV.1918, BMNH geometrid genitalia slide 11307 .

Additional material studied. Thalland: 10 , Mae Hongson Prov., Khun Yuom Distr., Ban Hua Pon, 900 m, 25.VII.1983, genitalia slide 1571. $20^{\circ}$, Chiengmai Prov., forest place near road Chiengmai-Chiengdao, km 55, 400 m, 6.II.1982, genitalia slide 1139, 1148. 1 \%", ibid. but Doi Saket Distr., above Ban Pang Hai, 950 m, 21.IX.1986, genitalia slide 2320. $10^{\prime}$, Thoen Prov., Ban Rin (some $50 \mathrm{~km} \mathrm{~S}$ of Thoen Town), $160 \mathrm{~m}, 11 . X I .1965$, genitalia slide 316. $1 \sigma^{\circ}$, Saraburi Prov., Sam Lann Nature Reserve, 21.IX.1975, genitalia slide 572, all Bänziger leg., in Bänziger coll.

$\mathrm{D}$ i a $\mathrm{g} \mathrm{n}$ o s i s. Close to $S$. lannaensis n. sp. from which it differs as mentioned in the description. The similar $S$. apataria and $S$. elvirata are larger (29-35 and 29-34 mm, $\varnothing=32$ and $31 \mathrm{~mm}, \mathrm{n}=9$ and 19 , respectively; S. triangulata $27-29 \mathrm{~mm}, \varnothing=27.5 \mathrm{~mm}$, $\mathrm{n}=5$ ) and have a characteristic dark yellow hind wing underside (dark and light greyish bands and dots in $S$. triangulata), and their genitalia are distinct in having more or less conspicuous processess on the ventral lobe of the valve. The genitalia are also close to, but certainly not the same as, those of $S$. compsogramma Wehrli, 1932; also, the facies of this is quite different and the wingspan larger $(31-34 \mathrm{~mm}, \varnothing=32 \mathrm{~mm}, \mathrm{n}=3)$ (type material of Museum Alexander Koenig, Bonn, and BMNH was studied).

Biology. S. triangulata is zoophilous (BÄNZIGER 1973, and in prep.).

Comment. Like $S$. eleonora and $S$. elephantedestructa, $S$. triangulata has a very light dry season form (Fig. 21). 


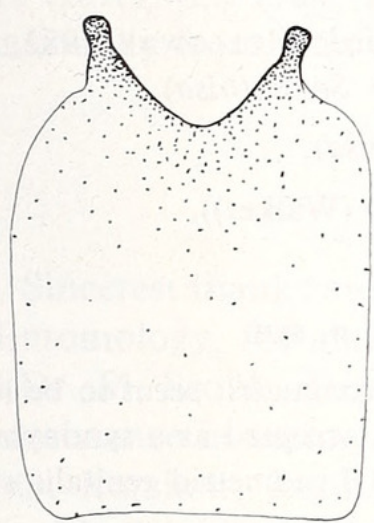

39

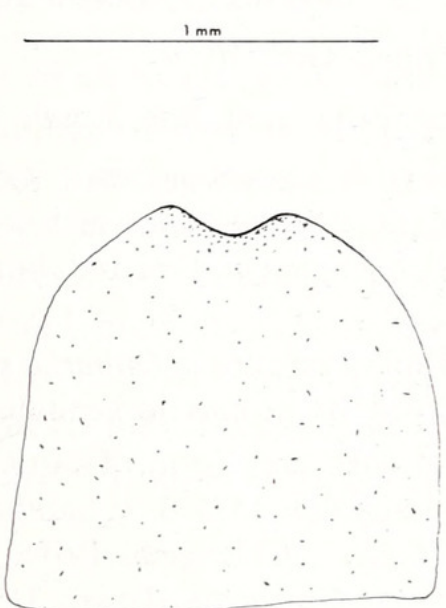

40
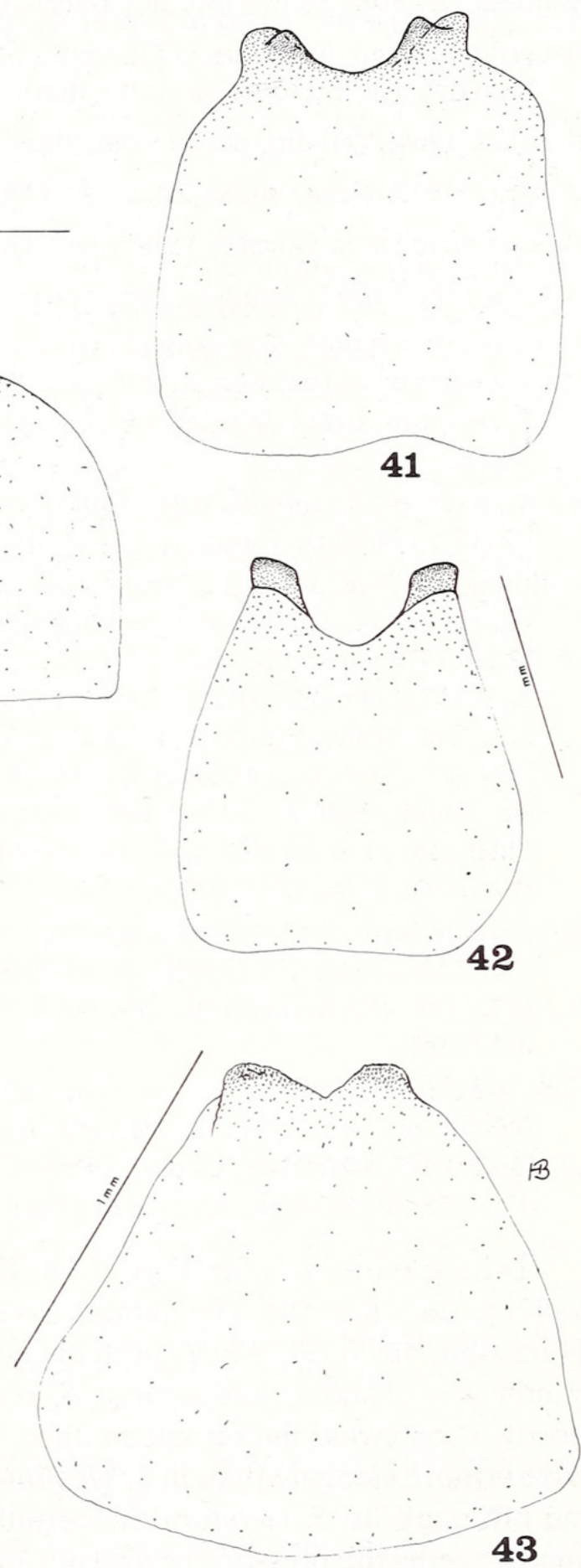

Figs 39-44.

8th sternite of male genitalia of Semiothisa triangulata (Hampson) (39), Semiothisa suthepensis n. sp. (40), Semiothisa lannaensis n. sp. (41), Semiothisa lacriphaga n. sp. (42), Semiothisa hollowayi n. sp. (43), Semiothisa elephantedestructa n. sp. (44). 


\section{Semiothisa eleonora (Stoll)}

Figs 15-18

Phalaena eleonora Stoll, 1780, in Cramer, Uitlandsche Kapellen 3: 172, pl. 288, Figs E, F, G.

Phalaena fasciata Fabricius, 1775, Ent. Syst. Suppl.: 629. Preoccupied (Holloway 1982, in:

BARLOW, An introduction to the moths of South East Asia, 249, as Semiothisa).

BütTIKeR 1964, Verhdlg. naturf. Ges. Basel 75: 233, Fig. 9 (as Semiothisa).

BÄNZIGER 1973, Revue suisse Zool. 79: 1400 (as S. fasciata and S. nora (Walker)).

Gubaria victorinata Guenée, 1858, Spec. Gen. 10: 9.

Gubaria subalbataria Swinhoe, 1889, Proc. zool. Soc. Lond. 1889: 428, n. syn.

Type material studied. The syntypes of S. eleonora: InDIA, Côte de Coromandel, seem to be lost.

The identity is based on $S$. [Gubaria] victorinata which is generally accepted as a synonym of

S. eleonora: INDIA, labelled "Victorinata Gn. type Ind. bor.", BMNH geometrid genitalia slide 11276.

Holotype $\sigma^{\prime}$ of $S$. subalbataria: INDIA, labelled "Gubaria subalbataria Swinhoe type $o$ ", and “2212 o", Nilgiris, Hampson”, BMNH geometrid genitalia slide 11301.

Additional material studied. Typical dark grey form. Thailand: $1 \sigma^{\circ}$, Mae Hongson Prov., Sop Poong, 650 m, 24.VII.1983, genitalia slide 1575. 1 o , Saraburi Prov., Sam Lann Nature Reserve, 12.IX.1979, genitalia slide 2376. $20^{\circ}$, Chiengmai Prov., foot of Doi Suthep, $330 \mathrm{~m}, 19$., 20.V.1973, genitalia slide 2373. 1 o , Chiengmai Town, $315 \mathrm{~m}, 24$. V.1982, genitalia slide 2372 . $1 \sigma^{\circ}$, Doi Suthep-Pui Natl. Park, Doi Khun Chang Khian, 1340 m, 27.X.1980, genitalia slide 2374. 1 o , Doi Chiengdao, NW Pass, 1150 m, 25.VI.1986, genitalia slide 2201. 1 o , Fang Distr., Ban Khom, 1470 m, 30.VII.1985, genitalia slide 1953. $50^{\circ}$, forest place near road ChiengmaiChiengdao, km 55, 400, 450, $500 \mathrm{~m}, 20 ., 29 . I V .1984$, 8.VIII.1981, 23.X.1980, genitalia slides $817,1693,1718,1721,2375$.

Intermediate form. $9 \mathrm{o}^{\circ}$, ibid., 360-400 m, 20.IV.1984, 23.IV.1983, genitalia slides 1546, 1694, 1701, 1541-1543, 1545, 1549, 1698. 1 ơ, Om Koi Distr., Sop Lan, 620 m, 14.III.1985, genitalia slide 1842. 1 o', Doi Suthep-Pui Natl. Park, below Mahidol Waterfall, 1090 m, 15.III.1986, genitalia slide 2102 .

Light grey form (hitherto $S$. subalbataria). $80^{\circ}$, forest place near road Chiengmai-Chiengdao, 360-400 m, 16.I., 6.II., 20.III.1982, 6.IV.1984, genitalia slides 1092, 1093, 1097, 1141, 1142, 1193, 1685, 1688. 1 ơ, Cholburi Prov., Khao Khio Nature Reserve, 200 m, 5.I.1975, genitalia slide 555, all Bänziger leg., in Bänziger coll.

D i a g n o s i s. See Figs 15-18. The male genitalia have been figured in Holloway (1982, p. 267, Fig. 59). The habitus is very similar to $S$. nora (Walker) and S. fumipennis (Hampson, 1895). However, both are somewhat larger (33-38 and 37-40 mm, $\varnothing=35$ and $38 \mathrm{~mm}, \mathrm{n}=19$ and 5, respectively; S. eleonora $30-36 \mathrm{~mm}, \varnothing=32.6 \mathrm{~mm}, \mathrm{n}=34$ ) and have mostly a somewhat darker appearance. In the genitalia of $S$. nora the ventral lobe of the valve is more elongate than in S. eleonora and has a process, in S. fumipennis it is widened and bifurcate. In $S$. eleonora the cornutus has a blunt tip with or without one to several smaller teeth, the presence or absence of which is not correlated to light and dark forms.

Comment. Reasons for considering S. subalbataria an infrasubsnecific entity of S. eleonora were given in the introduction. Moreover, both forms have been found at the very same study site and on the same host species, the elephant, but at different times: the lightest forms about February-March, the dark ones in May-October, and intermediate forms during the intervening periods. In the most extreme light grey form only tiny, discal spots remain of the black markings, if at all; the white fasciae and white cilia become light grey as the remainder of the wings upperside. The wings underside is not much differentiated from the dark form. Other species with light and dark forms are 
S. elephantedestructa and $S$. triangulata, 2 further species at present under investigation and, apparently to a lesser extent, S. nora.

Biology. Males have frequently been seen feeding upon various body fluids, including tears (BÜTTIKER 1964; BÄNZIGER 1973, 1988, and in preparation) from mammals, and occasionally from man (Fig. 17).

\section{ACKNOWLEDGEMENTS}

Sincerest thanks are due first of all to Dr. J. D. Holloway, Commonwealth Institute of Entomology, for making a number of important type dissections, to Mr. A. Watson and Dr. M. Scoble, Department of Entomology, British Museum (Nat. Hist.), London, for assistance in various ways. Dr. D. Stüning, Museum Alexander Koenig, Bonn, and Dr. O. Karsholt, Zoological Museum, Copenhagen, permitted to study many crucial types. Mr. W. Nässig, J. W. Goethe University, Frankfurt, made some type preparations. The senior author is grateful to Dr. E. Diehl and Drs. T. and J. Whitten for their help during his study in Indonesia, and to his colleagues at the Department of Entomology, especially Mr. P. Sukumalanan, Dr. S. Budharugsa, Mr. U. Aritajat, for their continuous support and interest.

\section{REFERENCES}

BÄNZIgeR, H. 1973 (1972). Biologie der lacriphagen Lepidopteren in Thailand und Malaya. Revue suisse Zool. 79: 1381-1469.

- 1983. Lachryphagous Lepidoptera recorded for the first time in Laos and China. Mitt. schweiz. ent. Ges. 56: 73-82.

- 1987. Description of new moths which settle on man and animals in S.E. Asia (genera Thliptoceras, Hemiscopis, Toxobotys, Pyralidae, Lepid.). Revue suisse Zool. 94: 671-681.

- 1988. Lachryphagous Lepidoptera recorded for the first time in Indonesia (Sumatra) and Papua New Guinea. Heteroc. Sumatr. 2: 133-144.

BASTELBERGER, M. J. 1907. Beschreibung neuer und Besprechung weniger bekannten exotischer Geometriden. Jb. nassau. Ver. Naturk. 60: 73-90.

BütTIKER, W. 1964. New observations on eye-frequenting Lepidoptera from S.E. Asia. Verh. naturf. Ges. Basel 75: 231-236.

Fabricius, J. C. 1775. Systema Entomologiae. Lipsia, 832 pp.

Felder, C. \& A. F. Rogenhofer. 1874. Reise der Österreichischen Fregatte Novara um die Erde. Zool. Theil, 2, Wien: Tafel 128.

GuenÉe, M. A. 1858 (1857). In: Boisduval \& GuenÉE. Histoire naturelle des Insectes (Lépid.). Vol. 10. Librairie Encyclopédique de Roret, Paris, 584 pp. 
HAMPSON, G. F. 1891. Illustrations of typical specimens of Lepidoptera Heterocera in the collection of the British Museum. Part VIII, 144 pp. Brit. Mus. nat. hist., London.

- 1895. Description of new Heterocera from India. Trans. ent. Soc. Lond.: 277-315.

Holloway, J. D. 1976. Moths of Borneo, with special reference to Mount Kinabalu. Kuala Lumpur, Sun U Book, 264 pp.

- 1982. Taxonomic appendix. In: H. S. Barlow, An introduction to the moths of South East Asia. Kuala Lumpur, the author, 305 pp.

HÜBNER, J. 1818. Zuträge zur Sammlung exotischer Schmetterlinge. I: 1-32.

InOuE, H. 1971. The Geometridae of the Ryukyu Islands (Lepidoptera). Bull. Fac. domestic Sci., Otsuma Woman's Univ. 7: 141-179.

- 1976. Descriptions and records of some Japanese Geometridae (V). Tinea 10: 7-37.

- 1977. Catalogue of the Geometridae of Japan (Lepidoptera). Bull. Fac. domestic Sci., Otsuma Woman's Univ. 13: 227-346.

- 1978. New and unrecorded species of the Geometridae from Taiwan with some synonymic notes (Lepidoptera). Bull. Fac. domestic. Sci., Otsuma Woman's Univ. 14: 203-254.

Inoue, H., S. Sugi, H. Kuroko, S. Moriuti \& A. Kawabe. 1982. Moths of Japan. Vol. 1+2, 966 \& 552 pp., 392 pls., Tokyo.

LeECH, J. H. 1897. On Lepidoptera Heterocera from China, Japan and Corea. Ann. Mag. nat. Hist. 19: 297-349.

Moore, F. 1888 (1879). In: Hewitson, W. C. \& F. Moore. Descriptions of new Indian lepidopterous insects from the collection of the late Mr. W. S. Atkinson. Asiat. Soc. Bengal, Calcutta, 299 pp.

Stoll, C. 1780. In: Cramer, Uitlandsche Kapellen 3: 1-176.

Swinhoe, C. 1889. On new Indian Lepidoptera chiefly Heterocera. Proc. zool. Soc. Lond.: 396-432.

- 1893. New species of Oriental moths. Ann. Mag. nat. Hist. 12: 210-225.

TAms, W. H. T. 1924. List of the moths collected in Siam by E. J. Godfrey. J. nat. Hist. Siam Soc. 6: 229-289.

DU TolT, R. 1958. Annual Report of the Division of Entomology, Department of Agriculture, Pretoria, 1954-1955 (In: BüTTIKER 1964, not seen in the original).

WALKER, F. 1861. List of the specimens of Lepidopterous Insects in the collection of the British Museum. 23: 757-1020.

- 1863 (1862). List of the specimens of Lepidopterous Insects in the collection of the British Museum. 26: 1479-1796.

Warren, W. 1911. Description of some new Geometridae and Pyralidae from South Africa. Ann. S. Afr. Mus. 10: 19-30.

Wehrli, E. 1932. Neue ostasiatische Geometriden-Arten und -Rassen aus meiner Sammlung. (Lepid. Heteroc.). Int. ent. Z. 26: 334-373.

Note added in proof. A new synonym replacing S. placida (Moore, 1888) has just been found:

S. sufflata (Guenée, 1857). Details will be given in a forthcoming article on new Semiothisa. 


\section{$2 \mathrm{BHL}$ Biodiversity Heritage Library}

Bänziger, Hans and Fletcher, David Stephen. 1988. "Description of five new lachryphagous and zoophilous Semiothisa moths from SE Asia, with five new synonymies (Lepid., Geometridae)." Revue suisse de zoologie 95, 933-952. https://doi.org/10.5962/bhl.part.81940.

View This Item Online: https://www.biodiversitylibrary.org/item/128833

DOI: https://doi.org/10.5962/bhl.part.81940

Permalink: https://www.biodiversitylibrary.org/partpdf/81940

\section{Holding Institution}

Smithsonian Libraries

\section{Sponsored by}

Biodiversity Heritage Library

\section{Copyright \& Reuse}

Copyright Status: In Copyright. Digitized with the permission of the rights holder.

Rights Holder: Muséum d'histoire naturelle - Ville de Genève License: http://creativecommons.org/licenses/by-nc-sa/3.0/ Rights: https://www.biodiversitylibrary.org/permissions/

This document was created from content at the Biodiversity Heritage Library, the world's largest open access digital library for biodiversity literature and archives. Visit BHL at https://www.biodiversitylibrary.org. 